\title{
Radiological changes in asbestos cement workers
}

\author{
K Jakobsson, U Strömberg, M Albin, H Welinder, L Hagmar
}

\begin{abstract}
Objective-To explore associations between exposure to asbestos cement dust and radiographic findings in lung parenchyma and pleura.

Methods-Radiographs from 174 blue collar workers and 29 white collar workers from an asbestos cement plant formed one part of the study. Progression of small opacities was further studied in those 124 blue collar workers, for whom two radiographs taken after the end of employment were available. The median readings from five readers who used the full ILO 1980 classification were used. As exposure indices, time since start of employment, duration of employment, cumulative exposure, and average intensity of asbestos exposure were used. The influence of age and smoking was also considered in multiple logistic regression analyses.
\end{abstract}

Results-Small opacities (profusion $\geqslant 1 / 0$ ) were closely correlated with time related exposure variables, and showed weaker association with intensity based exposure variables. The odds ratio (OR) for small opacities was equal to $2 \cdot 8(90 \%$ CI $1 \cdot 2$, $6 \cdot 7)$ in the $>30 \mathrm{f}$ (fibre) $-\mathrm{y} / \mathrm{ml}$ group, compared with those in the $0-10 \mathrm{f}-\mathrm{y} / \mathrm{ml}$ group. Progression of at least two minor ILO categories after the end of employment was seen in $20 \%$. Also, pleural thickening was closely related to time. By contrast, costophrenic angle obliterations were not associated with the time related variables, but closely associated with the intensity of asbestos exposure, and tended to occur during employment. The OR was $4.5(90 \% \mathrm{CI} 1 \cdot 3,15)$ in the $>2 \mathrm{f} / \mathrm{ml}$ group, compared with those in the $0-1$ flml group.

Conclusions-In these workers, exposed mainly to chrysotile but also to small amounts of amphibole, the risk of radiographically visible parenchymal abnormality was substantially increased and strongly dependent on time related exposure variables. Progression was found long after the end of exposure. The findings on costophrenic angle obliterations, supposed to be sequelae of benign pleural effusions, were consistent with an immediate reaction triggered by intense asbestos exposure.

(Occup Environ Med 1995;52:20-27)

Keywords: chest $x$ ray; asbestos cement
Asbestosis is today in most instances a nonfatal, slowly progressive disease. Differences between work forces in exposure-response relations for radiological abnormality suggest both a fibre and a process effect. ${ }^{\prime}$ Differences in the slopes of the cumulative exposureresponse curves for the prevalence of radiological changes indicative of fibrosis have been found in cohorts of workers exposed to chrysotile. Thus, for miners and millers the slope is flat, whereas for textile workers, the slope is much steeper-a pattern similar to the findings for lung cancer. Data from the asbestos cement industry are not consistent. As the asbestos cement industry is now the largest user of asbestos fibres, ${ }^{2}$ and is still expanding in some parts of the world, there is a need for further information.

The prevalence of pleural abnormality exceeds that of parenchymal disease in most populations exposed to asbestos. Plaques on the parietal pleura can occur after slight exposure, slowly developing over decades, and usually cause a clinically negligible functional impairment. ${ }^{3}$ In contrast, diffuse pleural fibrosis, if extensive, may produce severe impairment of ventilation. Although it is evident from necropsy studies that the tissue fibre burden is greater in patients with diffuse pleural fibrosis than in patients with plaques alone, ${ }^{4}$ exposure-response relations for diffuse pleural fibrosis and for benign pleural effusions need to be better understood.

We here present a study of radiographic changes in asbestos cement workers, followed up until advanced age.

\section{Materials and methods}

SUBJECTS AND RADIOGRAPHS

The study base comprised 249 male blue collar workers with at least 10 years of employment at an asbestos cement plant, born in 1900 or later, and still alive on 1 January, 1978. This group represents $60 \%$ of all male blue collar workers, ever employed for at least 10 years at the plant. A limited number of workers with certain dusty tasks at the plant had been compulsorily examined at the Department of Radiology, Lund University Hospital, before and during employment since 1962, and all workers had been offered examinations in 1971 and 1974. Moreover, all ex-workers from the plant had been invited to health examinations in 1978 and 1984 . Also a small number of men, compensated for asbestosis, had been examined for medicolegal reasons. As the plant was situated in the local catchment area of this hospital, radiographs taken for clinical reasons were also available, but, 
Table 1 Characteristics of workers from an asbestos cement plant

\begin{tabular}{|c|c|c|c|}
\hline & \multicolumn{2}{|c|}{$\begin{array}{l}\text { Study based on first available radiograph of } \\
\text { asbestos cement workers }\end{array}$} & \multirow[b]{2}{*}{$\begin{array}{l}\text { Follow up study* } \\
(n=124)\end{array}$} \\
\hline & $\begin{array}{l}\text { Blue collar } \\
(n=174)\end{array}$ & $\begin{array}{l}\text { White collar } \\
(n=29)\end{array}$ & \\
\hline Age† & $58(25-79)$ & $49(31-66)$ & $70(38-85)$ \\
\hline $\begin{array}{l}\text { Smoking category }(\mathrm{n}(\%)) \text { : } \\
\text { Non-smoker } \\
\text { Ex-smoker } \\
\text { Smoker }\end{array}$ & $\begin{array}{r}29(17) \\
41(23) \\
104(60)\end{array}$ & $\begin{array}{r}6(21) \\
11(38) \\
12(41)\end{array}$ & $\begin{array}{l}19(15) \\
38(31) \\
67(54)\end{array}$ \\
\hline $\begin{array}{l}\text { Work related variablest: } \\
\text { Employed at investigation }(\mathrm{n}(\%)) \\
\text { Time since start of exposure }(\mathrm{y}) \dagger \\
\text { Duration of employment }(\mathrm{y}) \dagger \\
\text { Average intensity }(\mathrm{f} / \mathrm{ml}) \dagger \\
\text { Cumulative dose }(\mathrm{f}-\mathrm{y} / \mathrm{ml}) \dagger \\
\text { Start of employment } f\end{array}$ & $\begin{array}{c}120(69) \\
23 \cdot 5(2 \cdot 3-59) \\
19 \cdot 7(2 \cdot 3-51) \\
1 \cdot 0(0 \cdot 1-8 \cdot 6) \\
19(1 \cdot 8-196) \\
1951(1920-1967)\end{array}$ & $\begin{array}{c}2(7) \\
16 \cdot 7(3 \cdot 2-50) \\
7 \cdot 7(0 \cdot 5-49) \\
0 \cdot 0(0 \cdot 0-0 \cdot 6) \\
0 \cdot 0(0 \cdot 0-1 \cdot 4) \\
1962(1929-1975)\end{array}$ & $\begin{array}{c}-\overline{31 \cdot 3}(18-63) \\
21 \cdot 1(10-51) \\
0 \cdot 9(0 \cdot 1-4 \cdot 0) \\
19(2 \cdot 1-127) \\
1952(1920-1967)\end{array}$ \\
\hline $\begin{array}{l}\text { Time since end of employment }(y) \dagger \\
\text { Follow up time (betwen radiographs; }(y) \dagger\end{array}$ & - - & - $\quad-$ & $\begin{array}{l}8 \cdot 9(4-39) \\
6 \cdot 2(2-18)\end{array}$ \\
\hline
\end{tabular}

* Only blue collar asbestos cement workers for whom at least two radiographs after the end of employment were available.

tMedian (range).

$\pm W$ ith respect to last available radiograph in the follow up study.

unfortunately, a reduction of the archives has somewhat reduced the number of available radiographs. Radiographs were found for 174 men. A maximum of four radiographs for each person was included. We selected radiographs primarily from the years of the health examinations, and tried to get series with about four-year intervals between the films. Also, radiographs from 29 white collar workers examined in 1978 were included to provide information on men with no or minor asbestos exposure. There were 53 men with only one, 33 with two, and 117 with three or more radiographs.

We used the earliest available radiograph, taken after the start of employment in the plant for the prevalence study; $12 \%$ of the blue collar workers had at that time not yet been employed for 10 years. In the follow up study 124 blue collar workers with at least two radiographs after the end of employment were included. Table 1 shows group characteristics. For $96 \%$ of the radiographs in the prevalence study and for all pairs in the follow up study, high $\mathrm{kV}$ technique had been used. For $89 \%$ of the pairs in the follow up study, both examinations had been performed with the air gap technique.

\section{EXPOSURE}

\section{Asbestos}

The asbestos cement plant operated between 1907 and 1977. The asbestos handled was mainly chrysotile ( $>95 \%$ ), but small amounts of crocidolite and amosite had been used before 1966. Silica was not added, and Portland cement with low quartz content $(<0.1 \%$ crystalline quartz in the respirable fractions) was used. Details on the asbestos dust levels in the air of the production area, and the calculation of estimates of individual exposure have been reported elsewhere. ${ }^{5}$ Cumulative exposure up to the date of each radiograph was calculated. The average exposure intensity from the start of employment until each examination was found simply by dividing cumulative exposure by duration of employment. Table 2 shows the distribution of exposure indices in the study group. There was no systematic variation between the cal- endar year of a radiograph and estimated average intensity.

Lifetime occupational histories ip to 1978 were available for $95 \%$ of the asbestos cement workers. No exclusions were made, as only two workers indicated any notable asbestos or quartz exposure at any other workplace.

\section{Tobacco}

For the asbestos cement workers, detailed smoking histories were obtained in the 1978 and 1984 health examinations. Only $17 \%$ were lifelong non-smokers. Among the others, $98 \%$ had started to smoke before, or within the first two years of the start of employment at the plant.

\section{READING PROCEDURE}

Posterioanterior radiographs were classified independently by five readers according to the 1980 International Labour Organisation (ILO) classification of radiographs of pneumoconiosis. ${ }^{6}$ The radiographs were read in random order without knowledge of exposure history, age, or date of examination. Eighty four trigger films from the same laboratory were irregularly interspersed among the radiograph series. The median reading from a previous trial, in which the present readers had participated, ${ }^{7}$ was used as a gold standard.

Table 2 Chest $x$ ray film findings (median readings from first available radiographs) in workers from an asbestos cement plant

\begin{tabular}{lll}
\hline & \multicolumn{2}{l}{ Asbestos cement workers } \\
\cline { 2 - 3 } & $\begin{array}{l}\text { Blue collar } \\
(n=174) \\
n(\%)\end{array}$ & $\begin{array}{l}\text { White collar } \\
(n=29) \\
n(\%)\end{array}$ \\
\hline Small opacities, profusion: & $114(66)$ & $23(79)$ \\
$0 / 0$ & $22(13)$ & $4(14)$ \\
$0 / 1$ & $16(9)$ & $2(7)$ \\
$1 / 0$ & $18(10)$ & $0(0)$ \\
$1 / 1-1 / 2$ & $2(1)$ & $0(0)$ \\
$2 / 1+$ & & \\
Chest wall thickening: & $84(48)$ & $5(17)$ \\
Any thickening & $44(25)$ & $2(7)$ \\
Definite thickening & $33(19)$ & $1(3)$ \\
Definite circumscribed & $25(14)$ & $1(3)$ \\
thickening only & $15(14)$ & $1(3)$ \\
Any diffuse thickening & $14(8)$ & $1(0)$ \\
Diaphragmatic plaque & $15(9)$ & $1(3)$ \\
Costophrenic angle obliteration & & \\
Pleural strands & &
\end{tabular}


Small opacities of profusion $0 / 1$ were seen on $20 \%$ and profusion $\geqslant 1 / 0$ on $7 \%$ of the trigger films, and $21 \%$ had some chest wall thickening. The median reading for each item in the protocol was determined if at least three readers found it possible to classify (which for the various items was possible in $97-100 \%$ of the films). The median readings were used when comprehensive indices were calculated. Of 596 radiographs read, $91 \%$ were of good or acceptable quality, and $8 \%$ were of poor quality.

The individual readings for profusion of small opacities were in agreement with the median reading in $70 \%$ of the radiographs, and only $8 \%$ of all individual readings differed more than one minor category from the median. As hardly any rounded opacities were noted $(95 \%$ of all median readings positive for small opacities were either "s" or " $t$ ") only the category of profusion was considered. Parenchymal abnormality was defined as profusion $\geqslant 1 / 0$. In the follow up study of progression after the end of employment an increase of one minor category of profusion was seen in 30 out of 124 blue collar asbestos cement workers. Regression of one minor category was, however, found in 15 men. An increase of at least two minor categories was seen in 24 men, and there were no regressions of this magnitude. We defined progression as a change of at least two minor categories, and thus reduced misclassification of defined progression (assuming that no true regression exists; however, it has to be remembered that random misclassification can only go in the direction of progress in the lowest profusion categories).

The presence of diffuse and circumscribed chest wall thickenings were separately noted, but the protocol did not distinguish width and extent for each feature. The individual readings were in agreement with the median reading in $89 \%$ of all radiographs for the presence of both diffuse and circumscribed changes. In our analysis, any chest wall thickening and bilateral chest wall thickening denote circumscribed or diffuse chest wall changes regardless of size. Definite thickening was defined as the presence of any chest wall thickening with a width $>5 \mathrm{~mm}$ and extent $>1 / 4$ of the chest wall, or a diaphragmatic plaque. Further restrictions, which excluded firstly all cases with coexisting costophrenic obliteration, and secondly all cases with any diffuse thickening, were intended to represent cases with only parietal plaques denoted as definite circumscribed thickening only. Any diffuse thickening denotes the presence of diffuse chest wall thickening, regardless of its size or the coexistence of other pleural changes.

Costophrenic angle obliteration denotes an obliteration, defined as in the ILO standard radiographs, regardless of the presence or absence of other chest wall or diaphragmatic thickenings. The agreement between individual and median readings for costophrenic angle obliteration was $98 \%$.

The ILO reading protocol was extended, according to a recent proposal for revision of the ILO classification. ${ }^{8}$ The presence of pleural strands, radiating from the pleura into the parenchyma, either separate or confluent (crow's feet), or in connection with rounded atelectases were noted. Apical pleural thickenings were noted if the width was $\geqslant 1.0 \mathrm{~cm}$, the contour was downwardly convex and uneven, and if there was an assymetry. A thickening of the interlobar fissure of $\geqslant 1 \mathrm{~mm}$ was noted. Additional standard radiographs for these features were not provided. This may partly explain the considerable variation between the readers over the frequency of notation of these extensions on all 596 radiographs read; $3-15 \%$ for fibrous strands, $1-8 \%$ for apical thickenings, and $0 \cdot 5-10 \%$ for interlobar fissure thickening.

\section{STATISTICS}

We decided to analyse the impact of exposure on findings from the first available radiograph for each asbestos cement worker, because all workers were then included in the analysis and, also, the individual exposures had a relatively large variability when assessed at the time of the first radiographs. White collar asbestos cement workers were also included in the analysis to obtain a greater variation for exposure variables that incorporated a measure of intensity.

Usually, prevalence refers to a certain point of time; here it is defined with respect to the radiographs. The odds ratio (OR) was used as the effect measure for comparison between different categories of workers with respect to variables related to exposure. An odds equals $\mathrm{P} /(1-\mathrm{P})$, where $\mathbf{P}$ denotes the probability of a particular finding on the first available radiograph. Hence, it should be noted that the corresponding onset of abnormality occurred at some time before the first radiograph was taken. Logistic regression was used for estimation of ORs adjusted for age and smoking. ${ }^{9}$ Age was trichotomised (finer stratification implied no substantial residual confounding by age), and smoking was coded as nonsmoker, ex-smoker, and current smoker; these factors were regarded as potential confounders. When such a factor was included in a multivariate model, we tested whether there was evidence of interaction in the data; however, no significant interactions were found.

For blue collar workers, who had two radiographs after the end of employment, we considered progression (at least two minor categories of profusion) of small opacities. Let $T_{1}$ and $T_{2}$ denote the times of those radiographs $\left(T_{1}<T_{2}\right)$. The determinants considered in logistic regression analyses were: time between $T_{1}$ and $T_{2}$, age at $T_{2}$, smoking habit at $T_{2}$, average intensity, duration of employment, cumulative exposure, time between the end of employment and $T_{2}$, and profusion $(\leqslant 0 / 1 v \geqslant 1 / 0)$ at $T_{1}$.

\section{Results}

SMALL OPACITIES

Table 2 shows the distributions of ILO minor 
categories for profusion of small opacities in the first available radiographs from asbestos cement workers. Among the blue collar asbestos cement workers, $20 \%$ had profusion $\geqslant 1 / 0$. Among the white collar asbestos cement workers the corresponding figure was $7 \%$. As the age distribution and smoking habits of the white collar workers differed from those of the blue collar workers (table 1 ), this prevalence merely indicates the reading level of the panel, and cannot be directly compared with that of the blue collar asbestos cement workers.

Among the 38 blue collar asbestos cement workers with parenchymal abnormality, 18 had also definite chest wall thickenings, and one had an obliterated costophrenic angle.

The time related exposure variables, after controlling for age and smoking, were each associated with the presence of small opacities with profusion $\geqslant 1 / 0$ (table 3 ). These time related variables were clearly intercorrelated. Time since start of employment was most evidently associated with the presence of small opacities, with an OR of $7 \cdot 3$ (90\% CI 1.9-29) in the $\geqslant 30$ year group, compared with those in the $<15$ year group. The average intensity did not influence the probability of profusion $\geqslant 1 / 0$. The details of a model are exemplified with cumulative exposure as the exposure estimate (table 4). Alternatively when age was handled as a continuous variable (not in table) the result was similar. The effect of exposure was further emphasised when cate- gory $1 / 1$ was used as a more stringent cut off point (table 4).

Progression after the end of employment was seen in $20 \%$ of the men. The probability of progression increased with intensity and duration of employment, and was indicated also for time since the end of employment (table 5). Neither smoking and age, nor the initial

Table 4 Final multivariate logistic regression models, obtained in the analysis of the relation between the prevalence of small opacities and potential determinants (data were from 203 asbestos cement workers)

\begin{tabular}{|c|c|c|}
\hline Factor & $O R(9$ & $90 \%$ CI \\
\hline \multicolumn{3}{|c|}{$\begin{array}{l}\text { Model I (category of profusion } \geqslant 1 / 0 \text { ): } \\
\text { Cumulative dose: }\end{array}$} \\
\hline $\begin{array}{l}\leqslant 10 \mathrm{f}-\mathrm{y} / \mathrm{ml} \\
10-30 \mathrm{f}-\mathrm{y} / \mathrm{ml} \\
>30 \mathrm{f}-\mathrm{y} / \mathrm{ml}\end{array}$ & $\begin{array}{l}1 \cdot 0 \\
1 \cdot 1 \\
2 \cdot 8\end{array}$ & $\begin{array}{l}\overline{(0 \cdot 46,2 \cdot 6)} \\
(1 \cdot 2,6 \cdot 7)\end{array}$ \\
\hline \multicolumn{3}{|l|}{ Age: } \\
\hline $\begin{array}{l}\leqslant 54 \mathrm{y} \\
55-64 \mathrm{y} \\
\geqslant 65 \mathrm{y}\end{array}$ & $\begin{array}{l}1.0 \\
7.0 \\
4.5\end{array}$ & $\begin{array}{l}\overline{(2 \cdot 6}, 19) \\
(1 \cdot 4,14)\end{array}$ \\
\hline \multicolumn{3}{|l|}{ Smoking: } \\
\hline $\begin{array}{l}\text { Non-smoker } \\
\text { Ex-smoker } \\
\text { Smoker }\end{array}$ & $\begin{array}{l}1.0 \\
3.0 \\
3.9\end{array}$ & $\begin{array}{l}\overline{(0 \cdot 77,12) !} \\
(1 \cdot 0,14) !\end{array}$ \\
\hline \multicolumn{3}{|c|}{$\begin{array}{l}\text { Model II (category of profusion } \geqslant 1 / 1 \text { ): } \\
\text { Cumulative dose: }\end{array}$} \\
\hline $\begin{array}{l}\leqslant 10 \mathrm{f}-\mathrm{y} / \mathrm{ml} \\
10-30 \mathrm{f}-\mathrm{y} / \mathrm{ml} \\
>30 \mathrm{f}-\mathrm{y} / \mathrm{ml}\end{array}$ & $\begin{array}{l}1 \cdot 0 \\
5 \cdot 9 \\
13\end{array}$ & $\begin{array}{l}\overline{(0 \cdot 98,36)} \\
(2 \cdot 1,77)\end{array}$ \\
\hline \multicolumn{3}{|l|}{ Age: } \\
\hline $\begin{array}{l}\leqslant 54 y \\
55-64 y \\
\geqslant 65 y\end{array}$ & $\begin{array}{c}1 \cdot 0 \\
10 \\
6 \cdot 3\end{array}$ & $\begin{array}{l}\overline{(1} \cdot 7,58) \\
(0 \cdot 93,42)\end{array}$ \\
\hline \multicolumn{3}{|l|}{ Smoking: } \\
\hline $\begin{array}{l}\text { Non-smoker } \\
\text { Ex-smoker } \\
\text { Smoker }\end{array}$ & $\begin{array}{l}1.0 \\
0.93 \\
1.6\end{array}$ & $\begin{array}{l}\overline{(0 \cdot 20,4 \cdot 2)} \\
(0 \cdot 39,6 \cdot 1)\end{array}$ \\
\hline
\end{tabular}

Table 3 Impact of work related factors on chest $x$ ray film findings in 203 workers from an asbestos cement plant, obtained from logistic regression analyses based on median readings from first available radiographs

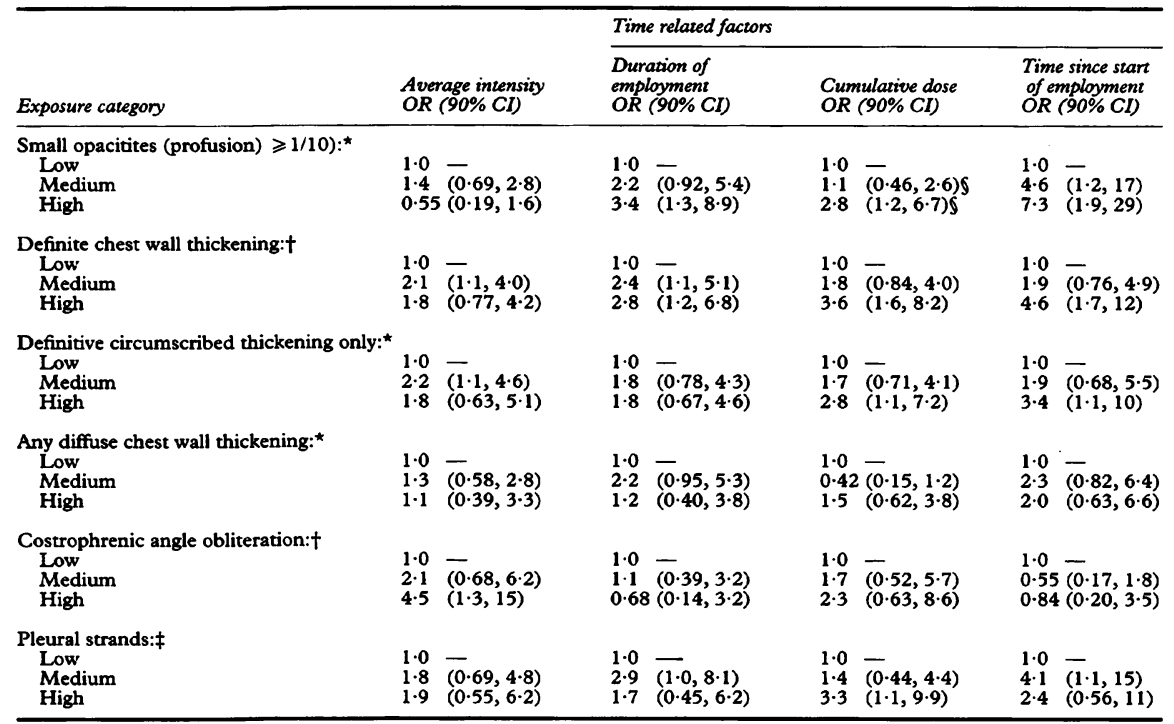

Low $=$ intensity $\leqslant 1 \mathrm{f} / \mathrm{ml}(\mathrm{n}=117)$; duration $\leqslant 14$ y $(\mathrm{n}=84)$; cumulative dose $\leqslant 10 \mathrm{f}-\mathrm{y} / \mathrm{ml}(\mathrm{n}=81)$; time since start of employment $\leqslant 14$ y $(n=57)$.

ment $\leqslant 14$ y (n employment $15-29$ y $(n=84)$.

High $=$ intensity $>2 \mathrm{f} / \mathrm{ml}(\mathrm{n}=25)$; duration $\geqslant 30 \mathrm{y}(\mathrm{n}=41)$; cumulative dose $>30 \mathrm{f}-\mathrm{y} / \mathrm{ml}(\mathrm{n}=50)$; time since start of employHigh $=$ intensity $>2 \mathrm{y} / \mathrm{m}$
ment $\geqslant 30$ y $(\mathrm{n}=62)$.

${ }^{\star}$ Adjusted for age and smoking category.

tAdjusted for age; no confounding effect of smoking category.

fAdjusted for smoking category; no confounding effect of age.

The model is presented in detail in table 4 (model $\mathrm{I}$ ). 
degree of profusion, were significant determinants for progression. Small opacities $\geqslant 1 / 0$ were found in $40 \%$ of the last radiographs (median 31 years after the start of employment).

\section{PLEURAL THICKENINGS}

The prevalence of any chest wall thickening on the first radiograph was $48 \%$ among the asbestos cement blue collar workers (table 2). Bilateral changes were seen in $30 \%$. Of those with chest wall thickenings, $67 \%$ had circumscribed thickenings only, $15 \%$ had diffuse thickenings only, and $19 \%$ had both types of changes. Among the white collar workers the prevalence of any chest wall thickening was $17 \%$.

The time related variables, after controlling for age, were each associated with the presence of definite chest wall thickening (table 3). Smoking category had no impact. In a further analysis (not in table) the intensity of exposure, with age and duration of employment included in the model, contributed significantly, with an OR of $2 \cdot 1(90 \%$ CI $1 \cdot 1,4 \cdot 1)$ in the $1-2 \mathrm{f} / \mathrm{ml}$ group, and OR $2 \cdot 2(90 \%$ CI $0.90,5 \cdot 2)$ in the $>2 \mathrm{f} / \mathrm{ml}$ group.

The findings for definite circumscribed thickenings were similar. In a further analysis (not in table) the intensity of exposure contributed to an OR of $2.3(90 \%$ CI $1 \cdot 1,4.8)$ in the 1-2 $\mathrm{f} / \mathrm{ml}$ group, and an OR of $2 \cdot 2(90 \%$ CI $0.76,6.5)$ in the $>2 \mathrm{f} / \mathrm{ml}$ group after adjustment for age, duration of employment, and smoking (for which a very small confounding effect was found).

The presence of any diffuse chest wall thickening showed weak or no relations with the exposure variables examined.

OBLITERATION OF THE COSTOPHRENIC ANGLE Among the blue collar asbestos cement workers, the prevalence of obliteration of the costophrenic angle was $8 \%$ (table 2). Of the 14 radiographs, two showed bilateral obliterations, and 10 showed a diffuse ipsilateral chest wall thickening. On one radiograph there were small opacities $\geqslant 1 / 0$. Among the white collar workers there were no obliterations.

Among the 14 asbestos cement workers

Table 5 Final multivariate logistic regression model, obtained in the analysis of the relation between progression of small opacities after the end of employment and potential determinants (data were from 123 blue collar asbestos cement workers (one missing))

\begin{tabular}{lc}
\hline Factor & $O R(90 \% \mathrm{CI})$ \\
\hline $\begin{array}{l}\text { Average intensity }(\mathrm{f} / \mathrm{ml}): \\
\quad \leqslant 1(\mathrm{n}=68)\end{array}$ & $1 \cdot 0-$ \\
$1-2(\mathrm{n}=44)$ & $1 \cdot 4(0 \cdot 54,3 \cdot 4)$ \\
$>2(\mathrm{n}=11)$ & $6 \cdot 7(1 \cdot 8,25)$ \\
Duration of employment $(\mathrm{y}):$ & \\
$\quad \leqslant 14(\mathrm{n}=35)$ & $1 \cdot 0-$ \\
$15-29(\mathrm{n}=53)$ & $3 \cdot 2(0 \cdot 75,14)$ \\
$\geqslant 30(\mathrm{n}=35)$ & $19(4 \cdot 1,84)$ \\
Time between end of employment and last radiograph $(\mathrm{y}):$ \\
$\leqslant 7 \cdot 5(\mathrm{n}=28)$ & $1 \cdot 0-\overline{0}$ \\
$7 \cdot 5-14(\mathrm{n}=73)$ & $1 \cdot 1(0 \cdot 39,3 \cdot 3)$ \\
$\geqslant 15(\mathrm{n}=22)$ & $3 \cdot 6(0 \cdot 91,14)$ \\
\hline
\end{tabular}

with obliterated costophrenic angles, one case of malignant mesothelioma was diagnosed 15 years after the appearance of the obliteration. No lung cancers have been found. Thus, we assume that all obliterations represent benign effusions. For none of these 14 radiographs did the readers comment on suspected tuberculosis or fractured ribs, and only one had a noted enlargement of the cardiac outline.

In contrast with the findings for parenchymal changes and other pleural changes, duration of employment and time since start of employment showed no association with the presence of obliterated costophrenic angles after adjustment for age (table 3 ). The average intensity was, however, clearly associated with obliterations with ORs of $4.5(90 \% \mathrm{CI}$ $1 \cdot 3-15)$ in the $>2 \mathrm{f} / \mathrm{ml}$ group and $2 \cdot 1(90 \% \mathrm{CI}$ $0 \cdot 68-6 \cdot 2$ ) in the intermediate group, compared with the $\leqslant 1 \mathrm{f} / \mathrm{ml}$ group. Smoking had no influence. We further studied all obliterations found before the age of 65 . Obliterations were found in nine out of 116 men during employment, whereas obliterations occurred in only one man out of 45 after the end of employment (Fisher's exact test; $P$ (two sided) $=0 \cdot 28$ )

\section{PLEURAL STRANDS}

Strands were seen on $9 \%$ of the first radiographs among the blue collar workers (table 2 ), and were associated with other pleural changes in all but three of the 15 radiographs. Nine radiographs also showed small opacities $\geqslant 1 / 0$. There was no radiograph with a median reading that indicated a rounded atelectasis. Only one of the 29 white collar workers had visible strands.

Neither time since the start of employment nor duration of employment were associated with strands (table 3 ). For the highest cumulative exposures, the risk was significantly increased. The point estimate also increased with increasing intensity (not significant; in the combined group $\geqslant 1 \mathrm{f} / \mathrm{ml}$ an OR of 1.8 , $90 \%$ CI $0 \cdot 76,4 \cdot 4$ was found).

\section{OTHER FEATURES}

Only two asbestos cement workers had apical pleural changes on the first radiograph available. With the last radiograph instead, there were 14 out of 124 blue collar asbestos cement workers with apical pleural changes. On all but one of these radiographs there were other chest wall thickenings, of which seven also included obliterated costophrenic angles. One radiograph showed small opacities in the upper zones of the lungs with an overall profusion of $2 / 3$, and eight others had small opacities $\geqslant 1 / 0$ elsewhere. Apical thickenings were not found among the white collar workers.

A thickened interlobar fissure on the first radiograph was noted in three asbestos cement blue collar workers. With the last radiograph instead, there were seven workers with fissural thickenings. In six of them, other chest wall thickenings were present. Three of them had profusion of small opacities $\geqslant 1 / 0$. Fissural thickenings were not found among the white collar workers. 


\section{Discussion}

In previous studies from this asbestos cement factory we have reported data on mortality and cancer morbidity, ${ }^{5}$ lung function, ${ }^{10}$ histopathological findings, ${ }^{11}$ and asbestos fibre content in lung tissue. ${ }^{12}$ Our present study adds complementary information on radiographical findings. The study base-men alive in the beginning of 1978-represents about $60 \%$ of all blue collar workers employed in the factory for at least 10 years. Radiographs were available for $70 \%$ of the men in the study base, however, only for three of the 16 men $(19 \%)$ who died during 1978 and 1979. Hence, the study investigates survivors. Although it is difficult to evaluate the overall selection bias, we believe that our results tend to underestimate, rather than overestimate the effects of exposure.

Independent randomised reading according to the ILO classification has been advocated whenever an estimate of prevalence is required from serial films because of the bias that may occur in side by side reading. ${ }^{13}$ Independent randomised reading was also used for determination of progression for feasibility reasons. The readers in our present study were jointly trained in the use of the ILO classification, which may explain the relatively small between observer variability. We used median readings in all analyses to reduce random variations in the outcome classification. The over or under reading level seems reasonable, as judged from the $7 \%$ prevalence for small opacities of profusion $\geqslant 1 / 0$ found in the white collar workers, compared with the reported $4 \%$ prevalence from a sample of men from the general population with a mean age of $50 . .^{14}$

The median cumulative asbestos exposure among the blue collar workers was $19(25,75$ percentiles $8 \cdot 6,47) \mathrm{f}-\mathrm{y} / \mathrm{ml}$. Thus, we are investigating men with low to moderate asbestos exposure on a group level. The validity of exposure estimates is crucial, when exposure-response relations are evaluated. Our estimates of airborne levels of asbestos fibres in the plant are substantially lower than those presented from some asbestos cement plants, ${ }^{15-17}$ but in the same range as in others. ${ }^{18} 19$ Both differences in the interpretations of results from early stationary sampling and real differences in the production technology between the plants are likely to contribute to these discrepancies. Detailed occupational histories were taken at a personal interview and from company data for most subjects. Thus, should we have underestimated exposure levels, we still assume that we have assigned the workers to the right category.

A further problem in any prevalence study, but not always recognised, is that the time of onset of an abnormality is not known. Duration of employment, cumulative exposure, and time since the start of employment to the onset of an abnormality will thus be overestimated. This might result in an underestimation of the slopes of these exposureresponse relations that assume fixed exposure categories. In contrast, average intensity would tend to be underestimated, assuming that exposure levels gradually diminished with time. In the follow up study, these drawbacks were reduced for the time related exposure variables, and disappeared for intensity.

\section{PARENCHYMAL ABNORMALITY}

Asbestosis was, in the days of intense exposures at the beginning of the century, a rapidly progressive disease. ${ }^{20}$ With the considerably lower exposure levels encountered later on, it has become evident that time since the start of exposure is an important predictor of the risk for onset and progression of radiologically detectable parenchymal abnormality. ${ }^{21-24}$ As in several other studies on the prevalence ${ }^{2225-27}$ and progression ${ }^{22-2428} 29$ of small opacities, time related variables such as duration of employment and cumulative exposure showed positive associations. Our findings for small opacities thus agree well with the present knowledge.

With $1 / 0$ as a cut off point for parenchymal abnormality, the estimated smoking effect was of the same magnitude as the effect in the highest exposure group. The point estimate for smoking agrees with estimates from other workforces exposed to asbestos. ${ }^{30}$ The use of $1 / 1$ as a cut off point for parenchymal abnormality instead of $1 / 0$ indicated a more pronounced impact of asbestos exposure, and considerably reduced the $\mathrm{OR}$ associated with smoking relative to the estimated effects of exposure-a finding that is consistent with the assumption that cigarette smoking in itself may cause mild, but not considerable fibrosis. ${ }^{31}$ Thus, the higher degrees of profusion probably reflect a more specific response to asbestos exposure.

The average intensity of exposure was not a determinant for the presence of small opacities in the prevalence study. Indeed, as exposure levels fall, personal characteristics may well assume a greater importance in determining not only the actual amount of fibres delivered to the lung tissue and retained there, but also the nature of the response. Workers with high average intensity had, however, an increased risk for progression after the end of employment, when duration of employment was taken into account. One can speculate that this finding actually reflects exposure of such a degree as to cause alveolar macrophage overload that resulted in diminished clearance and subsequently a higher tissue dose after exposure, which is not accurately represented by a cumulative exposure measure. ${ }^{32}$

In workers from the asbestos cement plant studied, fibrosis in histopathological slides from the lungs of deceased workers was more common and more pronounced than among controls. " In groups of workers with symptoms or signs suggestive of respiratory disease, functional changes were also found that reflected lung fibrosis ${ }^{10}$ and increased lung density in computerised chest radiographs. ${ }^{33}$ The mean estimated cumulative exposures in those study groups was about $20-25 \mathrm{f}-\mathrm{y} / \mathrm{ml}$. In our present study, the risk for small opacities $\geqslant 1 / 0$ was increased to almost threefold at $>30 \mathrm{f}-\mathrm{y} / \mathrm{ml}$. 
PLEURAL ABNORMALITY

Different types of pleural reactions are seen in association with asbestos exposure. The main reactions are parietal plaques on the one hand, and acute pleurisy and diffuse pleural fibrosis on the other. The original ILO 1971 classification did not allow for a clear distinction between circumscribed plaques and diffuse chest wall thickenings, and although an amendment was made in the 1980 revision, ${ }^{6}$ it is evident that a posteroanterior chest radiograph cannot always distinguish the two entities. In a longitudinal study of asbestos workers and controls further investigations in people with diffuse thickening, from reviews of clinical records, additional histories, oblique views, and other diagnostic procedures, showed that these thickenings were actually the result of multiple confluent plaques in $25 \% .{ }^{34}$ Such thickenings rarely extended to the costophrenic angle. Recent experience with high resolution computerised tomography scans have further shown the common coexistence of plaques and visceral pleural lesions, ${ }^{35}$ also indicated in our study. The difficulties of distinguishing between parietal plaques and visceral pleural lesions, with the ILO codes, are probably part of the explanation for the similarity in exposureresponse relation patterns found between the wider definition of pleural thickenings and the one intended to represent pleural plaques only.

Our findings on the exposure-response relations for pleural thickenings are consistent with present knowledge, with emphasis on the long period that is necessary for the development of visible thickenings, and the very small impact or absence of a smoking effect.' The common experience that even minor asbestos exposure may cause pleural plaques, provided the follow up period is long enough, was shown in this study, as a few cases occurred among the white collar workers.

Apical pleural changes have been ascribed to asbestos exposure, ${ }^{36}$ but may also be present in the general population. ${ }^{37}$ The prevalence of such changes as we defined them was low, and they were usually associated with other pleural changes. The prevalence of interlobar thickening was also low and, as previously found, seldom the only abnormal finding. ${ }^{38}$ More subtle definitions than those we used, combined with the use of lateral views, may be more sensitive for the diagnosis of thickening of the interlobar fissure, ${ }^{39}$ but with our robust criteria, such thickening was not an early sign of asbestos related disease.

In one longitudinal study, $31 \%$ of the cases with diffuse thickenings had had a previous benign pleural effusion, not related to trauma or infection. ${ }^{34}$ Resolution of an effusion that was ascribed to asbestos exposure usually $(>90 \%)$ resulted in an obliterated costophrenic angle. Resulting diffuse pleural thickenings were less frequent, about $50 \% .^{40}$ Thus, involvement of the costophrenic angle seems to be a more sensitive indicator of a previous episode of effusion than the presence of diffuse chest wall thickenings. For benign vis- ceral pleural reactions epidemiological evidence of a gradient in pathogenic potential by fibre type is scarce. ${ }^{41}$ In our study, all but one of the workers with involvement of the costophrenic angle had been working during the time when exposure to crocidolite or amosite might have occurred. The group of workers first employed after the disappearance of amphiboles in the production is, unfortunately, too small to evaluate the effects of chrysotile exposure only.

Pleural effusions appear suddenly, in contrast with the slowly developing parietal plaques. The biological mechanisms behind the pleural responses to asbestos fibres are, however, not elucidated. It is evident from necropsy studies that the tissue fibre burden is greater in patients with diffuse pleural fibrosis than in patients with plaques alone, ${ }^{4}$ but less than in patients with asbestosis. ${ }^{42}$ In our study, the exposure variables related only to time were not associated with an increased risk of obliterations, but average intensity, and to a lesser degree cumulative exposure, obviously were. That the risk is related to exposure intensity has also been indicated by previous findings. ${ }^{40}$ Our findings are in accordance with reports that benign effusions in workers exposed to asbestos occur with short latency after the onset of asbestos exposure..$^{40}$ The exposure-response patterns for obliterated costophrenic angles were thus greatly different from those we found for parenchymal and chest wall abnormalities. This may indicate differences in the underlying mechanisms of these changes.

The radiographs were classified by Gerd Lindén, Nils Stjernberg, and Göran Tornling. MA and $\mathrm{KJ}$ were trained by Charles E Rossiter. Bev Embrey handled all radiographs and the data collecting, for which Claes Hallström gave and the data collecting, for which Claes Hallstrom gave programming aid. Financial support was given by the Faculty of
Medicine, Lund University, and the Swedish Work Medicine, Lund

1 Becklake MR. Asbestos and other fiber-related diseases of the lungs and pleurn. Distribution and determinants in exposed populations. Chest 1991;100:248-54

Asbestos production. The chrysotile chrisis? Industrial minerals 1992;41-53.

3 Jones RN, McLoud T, Rockoff DS. The radiographic pleural abnormalities in asbestos exposure: relationship to physiol.

4 Stephens M, Gibbs AR, Pooley FD, Wagner JC. Asbestos induced diffuse pleural fibrosis: pathology and mineralogy. Thorax 1987;42:583-8.

5 Albin M, Jakobsson K, Attewell R, Johansson L, Welinder H. Mortality and cancer morbidity in cohorts of asbestos-cement workers and referents. $\mathrm{Br} \mathcal{F}$ Ind $\mathrm{Med}$ 1990;47:602-10.

6 International Labour Office. Guidelines for the use of ILO international classification of radiographs of pneumoconiosis. Geneva: IIO, 1980. (Occupational safety and health series No 22 revised.)

7 Construction Industry Foundation for Industrial Safety and Health. Evaluation of corporate health programme and Health. Evaluation of corporate health programme for chest $x$-ray screening of building workers exposed to quartz and/or asbestos dust. Stockholm: Construction Industry Foundation for Indus

8 Hillerdal G. Pleural lesions and the ILO classification: the need for a revision. Am F Ind Med 1991;19:125-30.

9 Hosmer DW, Lemeshow S. Applied logistic regression. New York: John Wiley, 1989.

10 Wollmer P, Eriksson L, Jonson B, Jakobsson K, Albin M Skerfving $S$, Welinder $H$. Relation between lung function, exercise capacity, and exposure to asbestos cement. Br f Ind Med 1987;44:542-9.

11 Johansson LG, Albin MP, Jakobsson KJ, Welinder HEC, Ranstam JP, Attewell RG. Ferruginous bodies and pulmonary fibrosis in dead low to moderately exposed monary forosis in dead low to moderately exposed Ind Med 1987;44:550-8.

12 Albin M, Johansson L, Pooley FD, Jakobsson K, Attewell R. Mitha R. Mineral fibres, fibrosis, and asbestos bodies 
in lung tissue from deceased asbestos cement workers. Brf Ind Med 1990;47:767-74.

13 McMillan GHG, Rossiter CE, Deacon R. Comparison of independent randomised reading of radiographs with direct scoring for assessing change in asbestos-related pulmonary and pleural lesions. Br $f$ Ind Med 1982; pulmonary

14 Kilbum $\mathrm{KH}$, Lilis $\mathrm{R}$, Anderson $\mathrm{HA}$, Miller A, Warshaw RH. Interaction of asbestos, age, and cigarette smoking in producing radiographic evidence of diffuse pulmonary in producing radiographic evidence

15 Hughes JM, Weill H, Hammad YY. Mortality of workers employed in two asbestos cement manufacturing plants. employed in two asbestos ceme

16 Finkelstein MM. Mortality among employees of an Ontario asbestos-cement factory. Am Rev Respir Dis 1984;129:754-61.

17 Raffn E, Lynge E, Juel K, Korsgaard B. Incidence of cancer and mortality among employees in the asbestos cement industry in Denmark. Br f Ind Med 1989;46:90-6.

18 Ohlson CG, Hogstedt C. Lung cancer among asbestos cement workers. A Swedish cohort study and a review. Brf Ind Med 1985;42:397-402.

19 Gardner MJ, Winter PD, Pannett B, Powell CA. Followup study of workers manufacturing chrysotile asbestos up study of workers manufacturing chrysotile

20 Cooke WE, Hill CF. Pneumokoniosis due to asbestos dust. Fournal of the Royal Microscopical Society 1927;48: dust. $232-8$.

21 Liddell D, Eyssen G, Thomas D, McDonald C. Radiological changes over 20 years in relation to chrysotile exposure in Quebec. In: Walton WH, ed. Inhaled particles and vapours IV. Oxford: Pergamon Press, 1977:799-812.

22 Cookson W, de Klerk N, Musk AW, Glancy JA, Armstrong B, Hobbs M. The natural history of asbestosis in former crocidolite workers of Wittenoom Gorge. $A m$ Rev Respir Dis 1986;133:994-8.

23 Sluis-Cremer GK, Hnizdo E. Progression of irregular opacities in asbestos miners. $\mathrm{Br} \mathcal{F}$ Ind Med 1989;46: 846-52.

24 Ehrlich R, Lilis R, Chan E, Nicholson WJ, Selikoff IJ. Long term radiological effects of short term exposure to
amosite asbestos among factory workers. $\mathrm{Br} \mathcal{F}$ Ind Med amosite asbestos

25 Rossiter CE, Bristol LJ, Cartier PH, Gilson JG, Grainger TR, Sluis-Cremer GK, McDonald JC. Radiographic changes in chrysotile asbestos mine and mill workers of Quebec. Arch Environ Health 1972;24:388-400.

26 Weill H, Waggenspack C, Bailey W, Ziskind M, Rossiter C. Radiographic and physiologic patterns among workers engaged in manufacture of asbestos cement products. A preliminary report. f Occup Med 1973; 15:248-52.

27 Liddell FDK, Gibbs GW. Radiological changes and fibre exposure in chrysotile workers aged 60-69 years at Thetford mines. Ann Occup Hyg 1982;26:889-98.

28 Becklake MR, Liddell FDK, Manfreda J, McDonald JC. Radiological changes after withdrawal from asbestos exposure. Brf Ind Med 1979;36:23-8.
29 Jones RN, Diem JE, Hughes JE, Hammad YY, Glindmeyer HW, Weill $H$. Progression of asbestos effects: a prospective longitudinal study of chest radiographs and lung function. $\mathrm{Br}$ F Ind Med 1989;46:97-105.

30 Blanc P, Gamsu G. Cigarette smoking and pneumoconiosis: structuring the debate. Am 7 Ind Med 1989;16:1-4.

31 Hnizdo E, Sluis-Cremer GK Effect of tobacco smoking on the presence of asbestosis at postmortem and on the reading of irregular op reading of irregular opacities on roentgenograms in 138:1207-12.

32 Smith TJ. Occupational exposure and dose over time: limitations of cumulative exposure. $\mathrm{Am} \mathrm{F}$ Ind $\mathrm{Med}$ 1992;21:35-51.

33 Wollmer P, Jakobsson $\mathrm{K}$, Albin $\mathrm{M}$, Albrechtsson U, Brauer K, Eriksson L, et al. Measurement of lung density by $x$ ray computed tomography. Relation to lung mechanics in workers exposed to asbestos cement. Chest 1987;92:865-9.

34 McLoud TC, Woods BO, Carrington CB, Epler GR, Gaensler EA. Diffuse pleural thickening in an asbestosexposed population: prevalence and causes. American Fournal of Roentgenology Radium Therapy and Nuclear Medicine 1985;144:9-18.

35 Solomon A, Rubin A-HE, Bar-Ziv J, Carel $R$. Inflammation of the visceral pleura, a nonspecific asbestos-related pleural reaction: chest radiograph and computed tomograph correlation. Am $f$ Ind $\mathrm{Med}$ computed tom

36 Hillerdal G. Pleural and parenchymal fibrosis mainly affecting the upper lung lobes in persons exposed to asbestos. Respir Med 1990;84:129-34.

37 Bohlig H, Calavrezos A. Development, radiological zone patterns, and importance of diffuse pleural thickening in relation to occupational exposure to asbestos. $\operatorname{Br} \mathcal{F}$ Ind Med 1987;44:673-81.

38 Solomon A, Irwig LM, Sluis-Cremer GK, GlynThomas $R$, du Toit RSJ. Thickening of pulmonary interlobar fissures: exposure-response relationship in crocidolite and amosite miners. Br f Ind Med 1979;36:195-8.

39 Rockoff SD, Schwartz A, Hix W, Rohatgi P, Kagan E, Kriebel D. Visceral pleural thickening in asbestos Kriebel D. Visceral pleural thickening in asbestos exposure: the occurrence and implications of thickened interlobar fissures. In: Proceedings from the VIIth International Pneumocon

40 Epler G, McLoud T, Gaensler E. Prevalence and incidence of benign asbestos pleural effusion in a working population. $\mathcal{F A M A} 1982 ; 247: 617-22$.

41 Merchant JA. Human epidemiology: a review of fiber type and characteristics in the development of malignant and nonmalignant disease. Environ Health Perspect 1990;88:287-93.

42 Roggli VL. Human disease consequences of fiber exposures: a review of human lung pathology and fiber burden data. Environ Health Perspect 1990;88:295-303.

43 Cookson WOCM, Glancy J, de Klerk NH, Armstrong BK, Musk AW, Hobbs MST. Benign and malignant pleural effusions in former Wittenoom crocidolite millers and miners. Aust NZ $\mathcal{J}$ Med 1985;15:731-7.

\section{Correspondence and editorials}

Occupational and Environmental Medicine welcomes correspondence relating to any of the material appearing in the journal. Results from preliminary or small scale studies may also be published in the correspondence column if this seems appropriate. Letters should be not more than 500 words in length and contain a minimum of references. Tables and figures should be kept to an absolute minimum. Letters are accepted on the understanding that they may be subject to editorial revision and shortening.

The journal also publishes editorials which are normally specially commissioned. The Editor welcomes suggestions regarding suitable topics; those wishing to submit an editorial, however, should do so only after discussion with the Editor. 